\title{
Essential oil composition of five Basil cultivars (Ocimum basilicum) from Albania
}

\author{
Nefrus Cheliku ${ }^{1}$, Ivana Cvetkovikj Karanfilova ${ }^{2 *}$, Gjoshe Stefkov², \\ Marija Karapandzova ${ }^{2}$, Nikoll Bardhi ${ }^{3}$, Bujar Qjazimi ${ }^{2}$ and Svetlana Kulevanova ${ }^{2}$ \\ ${ }^{1}$ Ministry of Agriculture, Forestry and Water Economy, Aminta Third No. 2, 1000 Skopje, Republic of Macedonia \\ ${ }^{2}$ Institute of Pharmacognosy, Faculty of Pharmacy, Ss. Cyril and Methodius University, \\ Majka Tereza 47, 1000 Skopje, R. Macedonia \\ ${ }^{3}$ Department of Plant Production, Faculty of Agriculture and Environment, \\ Agriculture University of Tirana, Kodër-Kamëz, Tirana, Albania
}

Received: July 2015; Accepted: September 2015

\begin{abstract}
Basil (Ocimum basilicum L., fam. Lamiaceae) is an important medicinal and aromatic plant with very wide range of uses. This paper presents qualitative and quantitative analyses of essential oils obtained from five types of Italian basil cultivars: Napolitan, Red basil, Fino Verde, Limonez, and Genoveze culltivated in Albania and collected during the summer 2012.

The hydrodistilled BEO (Basil essential oil) content ranged from $0.11 \%$ to $3.40 \%$. Within the total of 65 identified compounds with GC/FID/MS, nine were considered as predominant (1,8-cineole, linalool, cis-thujone, methyl chavicol, eugenol, trans-(E)-caryophyllene, trans- $(\alpha)$-bergamotene, germacrene D, and epi- $\alpha$-cadinol) representing 49.20 to $85.43 \%$ of the components in the analysed essential oils. In all cultivars, linalool was detected as the most abundant component (36.20-46.59\%).

BEO's from all five cultivars differ in their chemical composition but generally conform to EO's from Sweet Basil grown in the Medditeranean region. The Napolitan cultivar showed the largest similarity to Sweet Basil, not only for the morphology, also due to the essential oil composition that comprises Basil's most dominant chemical components (linalool, methyl chavicol and eucalyptol) in particular percents.
\end{abstract}

Keywords: Napolitan, Red basil, Fino Verde, Limonez, Genoveze, volatile oil, GC-MS analysis

\section{Introduction}

Common basil (Ocimum basilicum L.), a member of the Lamiaceae family is an annual herb which grows in several regions around the world. Among more than 150 species of the genus Ocimum, basil is the major crop which is cultivated commercially in many countries ( $\mathrm{Sa}-$ jjadi, 2006). Different authors have grouped basil into a subgenus based on its chemical composition or morphol-

\footnotetext{
*ivanacvetkovikj@ff.ukim.edu.mk, ivanacvetkovikj@gmail.com
}

ogy (Imeri et al., 2014). There are many cultivars of basil which vary in their leaf color (green or purple), flower color (white, red, purple) and aroma (Morales and Simon, 1996), but most of commercial basil cultivars available in the market belong to the species O. basilicum. Acoording to Darrah (1980), these cultivars are classified in seven types: (1) tall slender types, which include the sweet basil group; (2) large-leafed, robust types, including 'Lettuce Leaf' also called 'Italian' basil; (3) dwarf types, which are short and small leafed, such as 'Bush' basil; (4) compact types, also described, O. basilicum var. thyrsiflora, 
commonly called 'Thai' basil; (5) purpurascens, the purple-colored basil types with traditional sweet basil flavor; (6) purple types such as 'Dark Opal', a possible hybrid between $O$. basilicum and $O$. forskolei, whith lobed-leaves and a sweet basil plus clove-like aroma; and (7) citriodorum types, which include lemon-flavored basils. The most popular and commonly cultivated is Sweet Basil (Genovese, Large leaf, Lettuce Leaf, Mammoth).

Traditionally, basil has been extensively utilized in food, as a flavoring agent, as well as in perfumery and pharmaceutical or cosmetic industries (Telci et al., 2006). In folk medicine, leaves and flowering tops of the plant are perceived as carminatives, galactogogues, stomachics and antispasmodics (Sajjadi, 2006). However, recently the potential uses of basil essential oil (BEO), particularly as antimicrobial and antioxidant agents have also been investigated (Politeo et al., 2007; Sartoratotto et al., 2004; Wannissorn et al., 2005). The $O$. basilicum essential oils exhibited a wide and varying array of chemical compounds, depending on variations in chemotypes, leaf and flower colors, as well as aroma and origin of the plants (Sajjadi, 2006).

However, only a few articles have examined the yield and composition of essential oils of Basil cultivars, excpecialy from Albania (Cheliku et al., 2015; Keita et. al., 2000; Morales and Simon, 1996), therefore the aim of this study was chemical characterization of essential oils of Napolitan, Red basil, Fino Verde, Limonez, and Genoveze cultivars planted in Albania.

\section{Experimental}

\section{Plant collection}

The over-ground parts of the flowering plants (20-25 $\mathrm{cm}$ from the top) were obtained from five types of Italian basil cultivars: Napolitan, Red basil, Fino Verde, Limonez, and Genoveze cultivated and collected in Albania, during the summer 2012. The plant material was air dried, packed in paper bags and kept in a dark and cool place until analysis. Voucher specimens were deposited at the Institute of Pharmacognosy, Faculty of Pharmacy, Skopje (Napolitan - Ob/Al-N/12, Red basil - Ob/Al-RB/12, Fino Verde Ob/ Al-F/12, Limonez - Ob/Al-L/12, and Genoveze - Ob/Al$\mathrm{G} / 12$ ).

\section{Essential oil isolation}

Essential oil isolation from basil was performed by hydrodistillation in all-glass Clevenger apparatus for $2.5 \mathrm{~h}$, according to the method described in the European Pharmacopoeia (Ph. Eu. 8.0., 2014).

\section{Analysis of essential oil's chemical composition}

EO samples in hexane (1:1000) were analyzed on Agilent 7890A Gas Chromatography system equipped with
FID detector and Agilent 5975C mass spectrometer. For this purpose, HP-5 ms capillary column $(30 \mathrm{~m} \mathrm{x} 0.25 \mathrm{~mm}$, film thickness $0.25 \mu \mathrm{m}$ ) was used. Adam's analytical conditions were as follows: oven temperature at $60{ }^{\circ} \mathrm{C}(0 \mathrm{~min})$, $3{ }^{\circ} \mathrm{C} / \mathrm{min}$ to $240{ }^{\circ} \mathrm{C}(1 \mathrm{~min})$ and at the end increased to $280{ }^{\circ} \mathrm{C}$ at a rate of $10{ }^{\circ} \mathrm{C} / \mathrm{min}(1 \mathrm{~min})$ (Adams, 2007); helium, as carrier gas, at a flow rate of $1 \mathrm{ml} / \mathrm{min}$; injector temperature $220^{\circ} \mathrm{C}$ and that of the FID detector $270{ }^{\circ} \mathrm{C}$. One $\mu l$ of each sample was injected at a split ratio of $1: 1$. The mass spectrometry conditions were: ionization voltage 70 $\mathrm{eV}$, ion source temperature $230{ }^{\circ} \mathrm{C}$, transfer line temperature $280{ }^{\circ} \mathrm{C}$ and mass range from 50 to $550 \mathrm{Da}$. The MS was operated in scan mode.

\section{Identification of the components}

The components were identified according to the aveliable literature considering their retention times (Adams, 2007), as well as Kovat's (retention) indices determined using a homologous mixture of normal alkanes (C9 - C25) analysed under Automated Mass Spectral Deconvolution and Identification System (AMDIS) conditions (AMDIS ver.2.1.).

Confirmation was done by comparing the mass spectra of components present in the BEOs with the reference spectra obtained from Nist, Wiley and Adams' mass spectra libraries. Quantification of the BEOs components was performed using the normalisation method of the GC/FID peak areas without any correction factors.

\section{Results and discussion}

\section{Essential oil yield and composition}

The BEO yield of five basil cultivars from Albania ranged from $1.10 \mathrm{ml} / \mathrm{kg}$ to $34.00 \mathrm{ml} / \mathrm{kg}(0.11-3.40 \%$ ) (Table 1). The highest yield was recorded in one Fino Verde cutivar (No.1) while the lowest was found in one Napoli$\tan$ cultivar (No.2).

GC/FID/MS analyses of the isolated BEOs revealed, a total of 65 compounds representing $89.23-99.95 \%$ of the oils (Table 1). Nine components were considered as predominant: 1,8-cineole (1.25-13.00\%), linalool (26.17$50.16 \%)$, cis-thujone $(0.25-6.56 \%)$, methyl chavicol (0.66$33.05 \%)$, eugenol (0.17-13.73\%), trans-(E)-caryophyllene (0.29-4.03\%), trans- $(\alpha)$-bergamotene (1.81-12.58\%), germacrene D (1.29-5.50\%), and epi- $\alpha$-cadinol (0.27-6.01\%) that represented 49.20 to $85.43 \%$ of the chemical composition of the analysed essential oils. However, linalool, eugenol, farnesene and elemol, were reported as major components of the oils of different $O$. basilicum chemotypes (Chalchat et al., 1999; Grayer et al., 1996; Marotti et al., 1996). Acording to our findings, linalool was the most abundant component identified in all investigated cultivars which complies with all literature data (Cheliku et al., 2015; Labra et al., 2004; Sajjadi 2006). Further- 


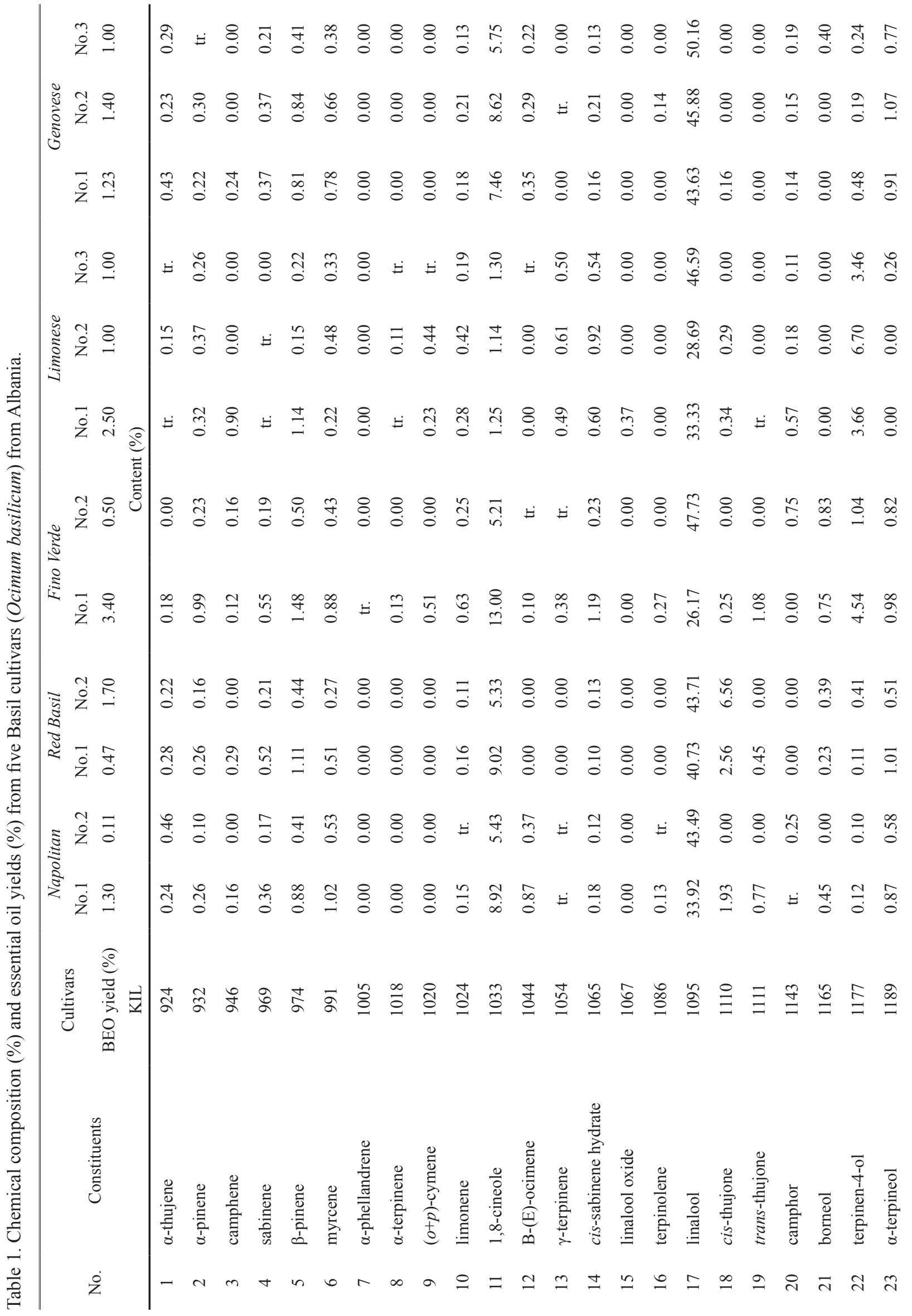

Макед. фарм. билт., 61 (2) 11 - 18 (2015) 


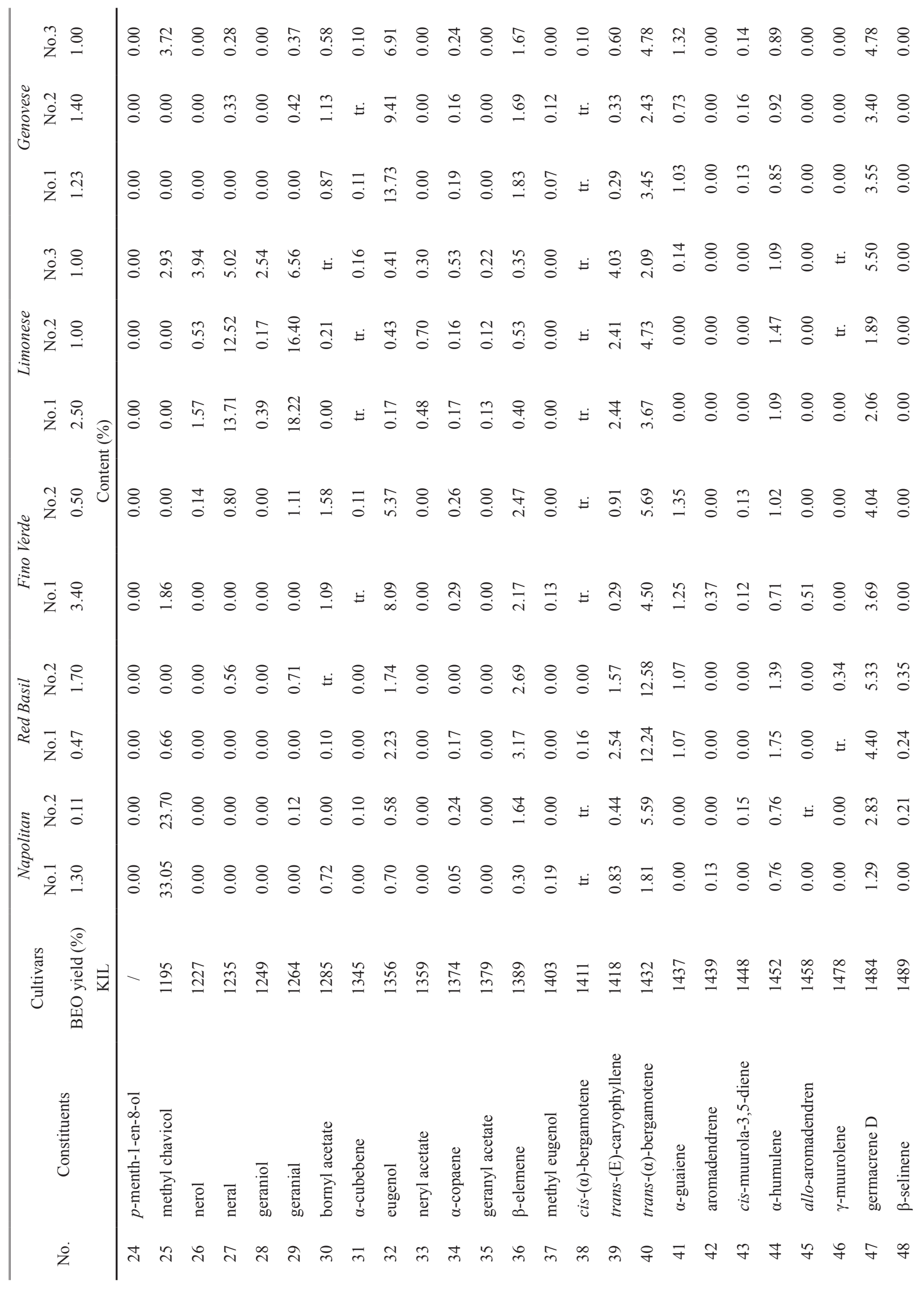




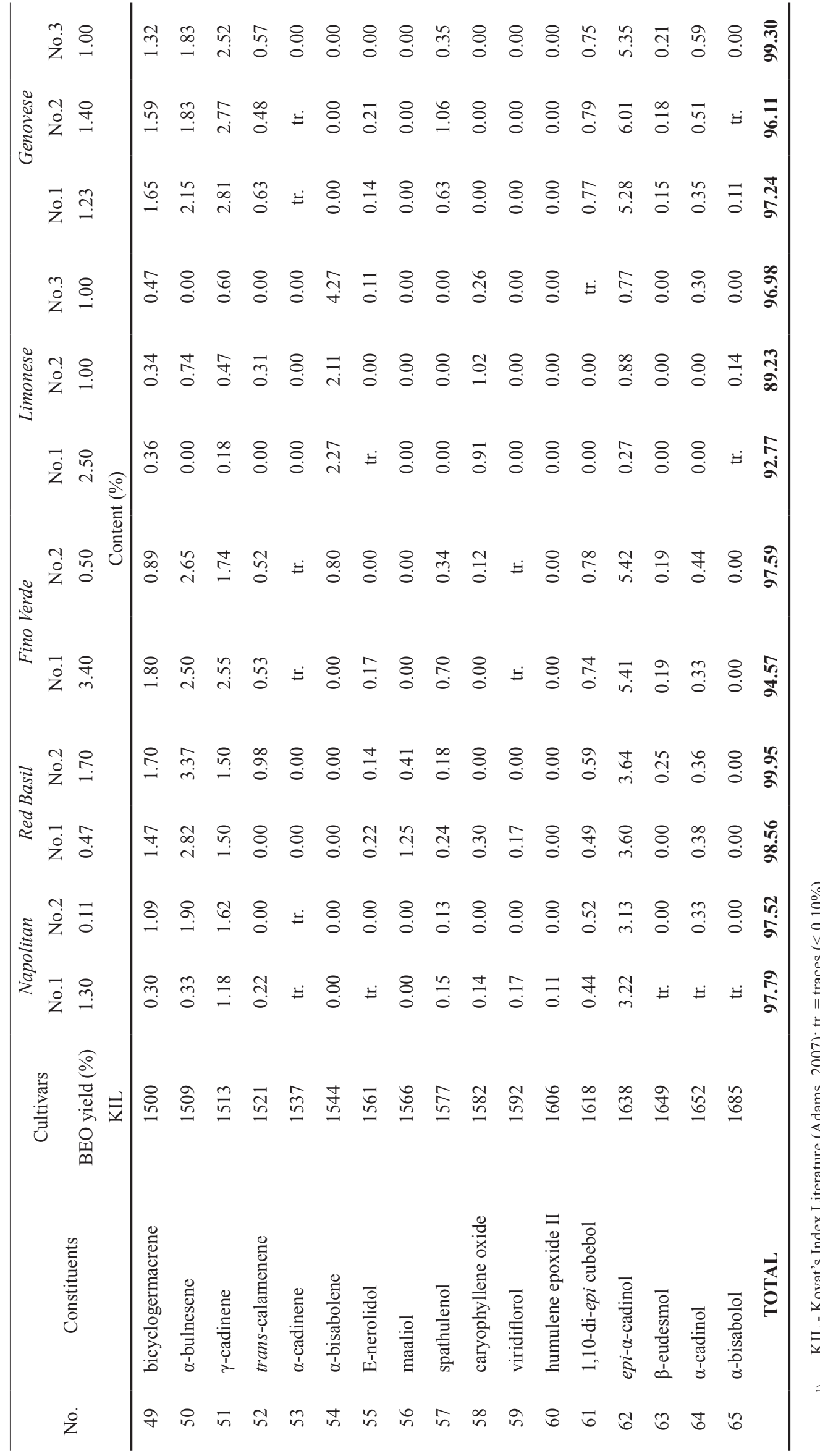

Макед. фарм. билт., 61 (2) 11 - 18 (2015) 


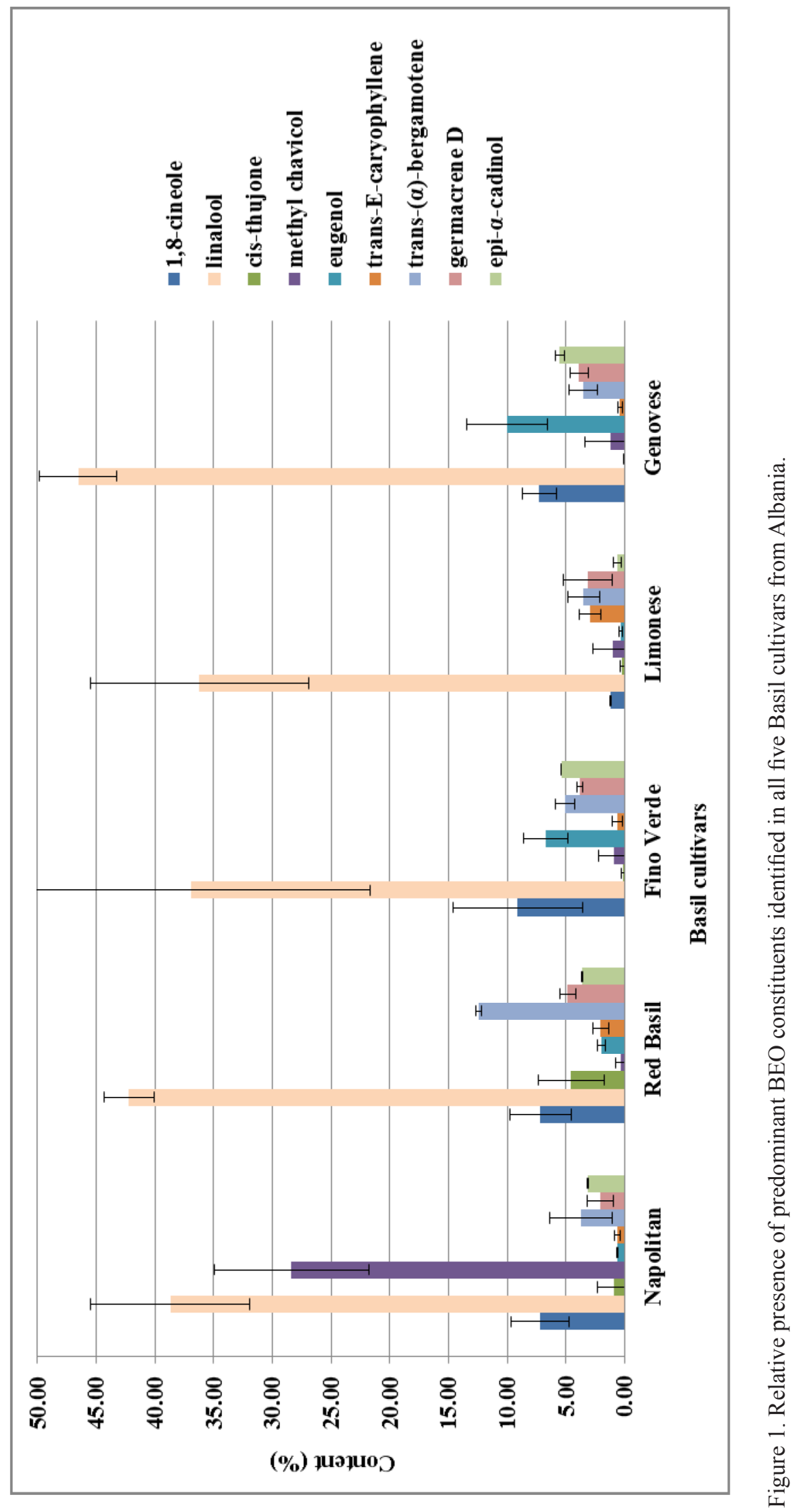

Maced. pharm. bull., 61 (2) 11 - 18 (2015) 
more, linalool was declared as dominant constituent in the two green and purple cultivars, with different leaves morphology (Raguso and Pichersky, 1999). In the volatile oils, obtained from aerial parts of $O$. basilicum grown in Colombia and Bulgaria, linalool was also reported as a major component (Benitez et al., 2009; Jirovetz and Buchbauer, 2001; Vina and Murillo, 2003). On the other hand, 1,8-cineole can be considered as the third main component in all examined samples that conforms with the data from the study of 65 Italian deifferent BEO's samples (Labra et al., 2004) (Fig. 1).

Regarding gas chromatography analyses, it is evident that the examined five basil cultivars had variances in the chemical composition of the essential oil (Fig. 1). The Napolitan cultivars often known as wide leaf cultivars, were reach in methyl chavicol (23.70-33.05\%), which is second abundand compound in the BEO thus it differs from all the other investigated cultivars. Red or purple basil is the only cultivar where trans-thujone (up to 6.56\%) and trans- $(\alpha)$ bergamotene (up to $12.58 \%$ ) were identified in significant amount. On the other hand, trans-(E)-caryophyllene was present in both, the Red basil and Limones cultivars. Also, characteristic for the Limonese cultivars was $\alpha$-bisabolene, which was absent in the other types of basil. In the composition of the BEO's of Fino Verde and Genovese samples, eugenol was found in significant amount (5.37-13.73\%) but was absent from the other examined cultivars.

High contents of linalool and methyl chavicol in Napolitan basil indicated that this cultivar could be considered as European originated chemotype with some influences of the North African (the Egyptian) chemotypes wich are with high methyl chavicol contents (Telci et al., 2005). Alike, geraniol and methyl chavicol were the main components in the oil of $O$. basilicum L. $c v$. purple from Turkey and Iran (Özcan and Chalchat, 2002; Sajjadi, 2006). Although the EO's of some Turkish and Bulgarian green basil were characterized by a high content of citral (neral and geranial) $(46.10 \%)$ and methyl cinnamate (Sajjadi, 2006), these were barely detected in our BEO's.

\section{Conclusion}

The yield of essential oils isolated from five different basil cultivars (Napolitan, Red basil, Fino Verde, Limonez, and Genoveze) from Albania ranged from $0.11 \%$ to $3.40 \%$. With GC/FID/MS analysis, total of 65 compounds were identified and nine of them were considered as predominant (1,8-cineole, linalool, cis-thujone, methyl chavicol, eugenol, trans-(E)-caryophyllene, trans- $(\alpha)$-bergamotene, germacrene $\mathrm{D}$, and epi- $\alpha$-cadinol), present in the BEO's with more than $5 \%$. The most abundant component detected in all cultivars was linalool.

BEO's from all five investigated cultivars differ in their chemical composition but generally conform to EO's from Sweet Basil grown in the Medditeranean region. The Napolitan cultivar showed the largest similarity to Sweet
Basil, not only for the morphology, also due to the essential oil composition that comprises Basil's most dominant chemical components (linalool, methyl chavicol and eucalyptol) in particular percents.

\section{References}

Adams, R.P., 2007. Identification of Essential Oil Components by Gas Chromatography/Mass Spectrometry. 4th Ed. Illinois: Allured Publishing Corporation, IL, USA, pp 9-31.

Automated Mass Spectral Deconvolution and Identification System software (AMDIS ver.2.1.), National Institute of Standards and Technology (NIST), Standard Reference Data Program, Gaithersburg, MD (USA).

Benitez, N., León, E.M.M., Stashenko, E.E., 2009. Eugenol and Methyl eugenol chemotypes of essential oil of species Ocimum gratissimum L. and Ocimum campechianum Mill. from Colombia. J. Chromatogr. Sci. 47, 800-804.

Celiku, N., Bardhi, N., Berisha, D., Doda, Q., Stevkov, Gj., Lazri, V., Nelaj, D., 2015. Essential Oil Composition in Three Cultivars of Ocimum basilicum L. in Albania. Online Int. Interdiscip. Res. J. ISSN 2249-9598, 13-17.

Chalchat, J.C., Garry, R.P., Sidibe, L. and Marama, M., 1999. Aromatic plants of Mali (I): Chemical composition of essential oils of Ocimum basilicum L. J. Essent. Oil Res. 11, 375-380.

Darrah, H.H., 1980. The cultivated basils. Buckeye Printing Company, Independence M O.

European Pharmacopoeia, 8th Edition, Council of Europe, Strasbourg, 2014.

Grayer, R.J., Kite, G.C., Goldstone, F.J., Bryan, S.E., Paton, A., Putievsky, E., 1996. Intraspecific taxonomy and essential oil chemo types in sweet basil, Ocimum basilicum. Phytochem. 43, 1033-1039.

Imeri, A., Kupe, L., Shenu, J., Dodona, E., Bardhi, N., Vladi, V., 2014. Essential oil composition in three cultivars of Ocimum L. in Albania. Arch. Biol. Sci., Belgrade, 66, 1641-1644.

Jirovetz, L., Buchbauer, G., 2001. Analysis chemo type and quality control of the essential oil of new cultivated basil (Ocimum basilicum L.) plant from Bulgaria. Sci. Pharm. 69, 8589.

Keita, S.M., Vincent, C., Schmit, J.P., Belanger, A., 2000. Essential oil composition of Ocimum basilicum L., O. gratissimum L. and $O$. suave L. in the Republic of Guinea. Flavour Fragr. J. 15, 339-341.

Labra, M., Miele, M., Ledda, B., Fabrizio Grassi, F., Mazzei, M., Sala, F., 2004. Morphological characterization, essential oil composition and DNA genotyping of Ocimum basilicum L. cultivars. Plant Sci. 167, 725-731.

Marotti, M., Piccaglia, R., Giovanelli, E., 1996. Differences in essential oil composition of basil (Ocimum basilicum L.) Italian cultivars related to morphological characteristics. Agric. Food Chem. 44, 3926-3929.

Morales, M.R., Simon, J.E., 1996. New basil selections with compact inflorescences for the ornamental market. In: Janick $\mathrm{J}$ (ed.), Progress in new crops. Arlington: ASHS Press. 543546.

Özcan, M., Chalchat, J.C., 2002. Essential oil composition of Ocimum basilicum L. and Ocimum minimum L. in Turkey. Czech J. Food Sci. 20, 223-228.

Politeo, O., Jukic, M., Milos., M., 2007. Chemical composition and antioxidant capacity of free volatile aglycones from basil 
(Ocimum basilicum L.) compared with its essential oil. Food Chem. 101, 379-385.

Raguso, R.A., Pichersky, E., 1999. A day in the life of a linalool molecule: chemical communication in a plant-pollinator system. Part 1: linalool biosynthesis in flowering plants. Plant Spec. Biol. 14, 95-120.

Sajjadi, S.E., 2006. Analysis of the essential oils of two cultivated basil (Ocimum basilicum L.) from Iran. DARU J Pharm. Sci. $14,128-130$.

Sartoratotto, A., Machado, A.L.M., Delarmelina, C., Figueira, G.M., Duarte, M.C.T., Rehder, V.L.G., 2004. Composition and antimicrobial activity of essential oils from aromatic plants used in Brazil. Braz. J. Microbiol., 35: 275-280.
Simon, J.E., M.R. Morales, W.B. Phippen, R.F. Vieira, and Z. Hao. 1999. Basil: A source of aroma compounds and a popular culinary and ornamental herb. p. 499-505. In: J. Janick (ed.), Perspectives on new crops and new uses. ASHS Press, Alexandria, VA.

Telci, I., Bayram, E., Yilmaz, G., Avci, B., 2006. Variability in essential oil composition of Turkish basils (Ocimun basilicum L.). Biochem. Syst. Ecol. 34, 489-497.

Vina, A., Murillo, E., 2003. Essential oil composition from twelve varieties of basil (Ocimum spp.) grown in Colombia. J. Brazil Chem. Soc. 14, 744-749.

Wannissorn, B., Jarikasem, S., Siriwangchai, T., Thubthimthed, S., 2005. Antibacterial properties of essential oils from Thai medicinal plants. Fitoterapia, 76, 233-236.

\title{
Состав на етерично масло од пет култивари на босилек (Oci- mum basilicum) од Албанија
}

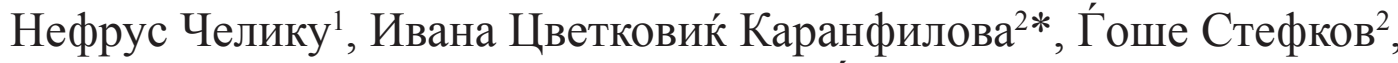 \\ Марија Карапанџова ${ }^{2}$, Никол Барди는 Бујар Казими и Светлана Кулеванова ${ }^{2}$
}

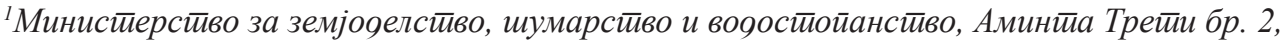 \\ 1000 Скойје, Рейублика Макеоонија

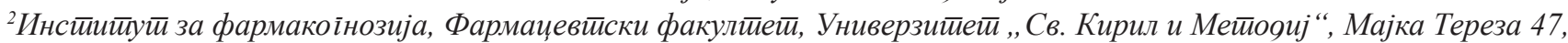 \\ 1000 Скойје, Рейублика Макеоонија \\ ${ }^{3}$ Оوяел за растиииелно ирроизвоясииво, Факулиееиоти за земјояелсииво и живойна среяина, \\ Земјояелски Универзииети оя Тирана, Кояер-Камез, Тирана, Албанија
}

Клучни зборови: Napolitan, Red basil, Finoverde, Limonez, and Genoveze, испарливи масла, GC-MS анализа.

Босилек (Ocimum basilicum L., фамилија Lamiaceae) е важно лековито и ароматично растение со многу широк опсег на употреба. Во овој труд е претставена квалитативната и квантитативната анализа на етеричните масла добиени од пет сорти на италијански босилек: Napolitan, Red basil, Finoverde, Limonez, и Genoveze, одгледани и собрани во Албанија, во текот на летото во 2012-та година.

Содржината на етеричното масло (ЕМ) добиена по дестилација со водена пара се движи од $0,11 \%$ до $3,40 \%$. Со GC/FID/MS анализа, идентификувани се вкупно 65 соединенија, од кои девет се сметаат како доминантни (1,8-цинеол, линалол, cis-тујон, метил кавикол, еугенол, trans-(Е)-кариофилен, trans-( $\alpha)$-бергамотен, гермакрен $\mathrm{D}$, и epi- $\alpha$-кадинол) и претставуваат 49,20-85,43\% од вкупниот број на компоненти во анализираните етерични масла. Кај сите испитувани сорти, линалолот е идентифкувана како најзастапена компонента (36,20-46,59\%).

Очигледно е дека ЕМ од сите пет различни сорти се разликуваат во однос на хемискиот состав, но генерално сите покажуваат голема сличност со ЕМ од типичниот Ocimum basilicum што се одгледува во медитеранскиот регион. Култиварот Napolitan може да се смета за најсличен со типичниот босилек, како поради неговата морфологија така и според хемискиот состав на маслото, за кое се поврзуваат хемиските компоненти линалол, метил кавикол и еукалиптол во сооднос што е карактеристичен за медитеранскиот босилек. 